\title{
Retraction: a descriptive study of a manual therapy intervention within a randomised controlled trial for hamstring and lower limb injury prevention
}

Wayne Hoskins ${ }^{*}$ and Henry Pollard

\begin{abstract}
The journal has been informed by its publisher BioMed Central that contrary to the statement in this article [Wayne Hoskins, Henry Pollard, Chiropractic \& Osteopathy 2010, 18:23], they have been advised by the authors' institution Macquarie University, that its Human Research Ethics Committee did not approve this study. Because the study was conducted without institutional ethics committee approval it has been retracted.
\end{abstract}

\section{Retraction}

The journal has been informed by its publisher BioMed Central that contrary to the statement in this article [1], they have been advised by the authors' institution Macquarie University, that its Human Research Ethics Committee did not approve this study. Because the study was conducted without institutional ethics committee approval it has been retracted.

Received: 5 September 2011 Accepted: 3 October 2011

Published: 3 October 2011

\section{Reference}

1. Hoskins W, Pollard H: A descriptive study of a manual therapy intervention within a randomised controlled trial for hamstring and lower limb injury prevention. Chiropr Osteopat 2010, 18:23.

Submit your next manuscript to BioMed Central and take full advantage of:

- Convenient online submission

- Thorough peer review

- No space constraints or color figure charges

- Immediate publication on acceptance

- Inclusion in PubMed, CAS, Scopus and Google Scholar

- Research which is freely available for redistribution

Submit your manuscript at www.biomedcentral.com/submit
() Biomed Central
C Biomed Central

(c) 2011 Hoskins and Pollard; licensee BioMed Central Ltd. This is an Open Access article distributed under the terms of the Creative Commons Attribution License (http://creativecommons.org/licenses/by/2.0), which permits unrestricted use, distribution, and reproduction in any medium, provided the original work is properly cited. 